УДК 94 (477) «1918»

ЗАДУНАЙСЬКИЙ В.В.

https://orcid.org/0000-0003-3971-3895

https://doi.org/10.33577/2313-5603.35.2021.125-141

\title{
СПОГАДИ Ф. І. ЄЛІССЄВА - ДЖЕРЕЛО ВИВЧЕННЯ ВОЄННОГО МИСТЕЦТВА КУБАНСЬКОЇ КОЗАЦЬКОЇ КІННОТИ ПІД ЧАС АНТИБІЛЬШОВИЦЬКОГО ПОВСТАННЯ У КАВКАЗЬКОМУ ВІДДІЛІ ВЕСНОЮ 1918 p.
}

Під час повстання кубанських козаків проти більшовицького режиму в Кавказькому відділі весною 1918 р. важливу роль відіграла кавалерія. Дуже цінним джерелом для вивчення воєнного мистецтва козацької кавалерії під час цього повстання $\epsilon$ мемуари талановитого козацького офіцера-кавалериста Ф. І. Слісєєва (командував усією кавалерією повстанців). Воєнне мистецтво козацької кавалерії під час повстання мало сильні сторони: козаки дуже гарно вели кінний бій; вони могли діяти й у пішому строю; козаки застосували 20 стратегем (частково 1); якісно діяла козацька передова сторожа під час нічного наступу. Недоліки: не мали кінної артилерії; поразка основних сил повстанців призвела до деморалізації козаків-кавалеристів і їх дезертирства. Попри поразку, козацька кавалерія виявила високий рівень воєнного мистецтва.

Ключові слова: воєнне мистецтво, стратегеми, Кубанське козацтво, кавалерія, Федір Єлісєєв, спогади, повстання, більшовицький режим, 1918 р., Кавказький відділ.

Постановка проблеми. У роки революції та Громадянської війни 1917-1920 pр. на території Північного Кавказу відбувались різноманітні бойові зіткнення, в яких активну участь брали кубанські козаки. Здебільшого їх формування боролися проти радянської влади. Прикладом цього $є$ й низка козацьких повстань, серед яких перше відбулося 19-24 березня (за новим стилем 1-6 квітня) 1918 р. у Кавказькому відділі колишньої «Кубанської області» (адміністративно-територіальна одиниця Російської імперії, в межах якої знаходилося Кубанське козацтво).

Враховуючи, що у бойових зіткненнях повсталі козаки покладалися виключно на власні сили, досить цікавим буде проаналізувати особливості їх воєнного мистецтва, щоб адекватно оцінити сильні й слабкі сторони їхнього військового потенціалу. При цьому окремої уваги заслуговує мистецтво ведення бою кінними загонами, які не тільки були своєрідною візитівкою усіх

Задунайський Вадим Васильович, доктор історичних наук, професор, професор кафедри історї Украӥнського католищького університету (м. Львів).

(C) Задунайський В. В., 2021 
козацьких утворень тих часів, але й відіграли ключову роль у бойових операціях Громадянської війни на всьому постімперському просторі.

3 огляду на обмеженість джерельної бази щодо повстання у Кавказькому відділі весною 1918 р., надзвичайно цінним видається його опис, зафіксований у мемуарах кубанського козацького офіцера Ф. І. Слісєєва, який був одним із керівників повстанців (Елисеев, 2003). Більше того, саме він як фаховий кіннотник, міг найбільш адекватно описати основні прояви воєнного мистецтва повстанської кавалерії. Тож вповні логічною видається спроба використання спогадів Ф. І. Єлісєєва для вивчення особливостей воєнного мистецтва кубанських козаків-кіннотників під час зазначеного повстання.

Аналіз попередніх досліджень і публікацій. Треба підкреслити, що в історіографії не тільки особливості воєнного мистецтва повсталих кубанських козаків, зокрема кінноти, але й саме повстання у згаданому відділі досі не стало предметом ретельного дослідження науковців. Натомість, вистачає публікацій, в яких розглядаються інші події на теренах колишньої «Кубанської області» впродовж 1917-1920-х рр. Прикладом є роботи А. Авраменка, В. Чумаченка, Б. Фролова, Д. Білого, В. Іваниса, С. Карпенка, В. Ратушняка, О. Ратушняка та інших (Авраменко \& Фролов \& Чумаченко, 2007; Білий, 2009; Іванис, 1968; Карпенко, 2006; Ратушняк В., 1996; Ратушняк О., 2005).

Поряд із цим, варто виокремити статтю російського вченого О. А. Леусяна «Фронт без лінії фронту»: козацькі повстання на Кубані весною 1918 року», в якій міститься короткий огляд головних подій згаданого повстання (Леусян, 2007). Цікаву інформацію про самого Ф. І. Слісєєва та узагальнену характеристику повстання представлено і в статті П. М. Стрелянова (Кулабухова) (Стрелянов, 2001).

Автор цієї розробки раніше вже аналізував особливості воєнного мистецтва кубанських козаків напередодні та під час революційних зрушень 1917 - початку 1920-х рр. (Задунайський, 2006; 2008). Окремо було вивчено й воєнні хитрощі повсталих кубанських козаків у Таманському і Баталпашинському відділах весною-літом 1918 р. з урахуванням досвіду їх предків, які належали до Чорноморського козацтва та низки інших українських козацьких формувань, що переселилися на терени Північного 
Кавказу (домінували в межах Кубанської області) $з$ кінця XVIII до 60-х років ХІХ століття (Задунайський, 2019; 2020). Відповідні напрацювання будуть корисними під час пропонованого дослідження 3 огляду на подібність обставин і змісту збройного протистояння в межах колишньої «Кубанської області».

Отже, в історіографії досі відсутнє комплексне дослідження особливостей ведення бою кубанською козацькою кавалерією під час антибільшовицького повстання в Кавказькому відділі весною 1918 p.

Метою статті є дослідження воєнного мистецтва кінноти кубанських козаків-повстанців у Кавказькому відділі весною 1918 р. на основі спогадів Ф. І. Слісєєва.

Виклад основного матеріалу дослідження. Перед безпосереднім аналізом змісту воєнного мистецтва повсталих кубанських козаків за спогадами Ф. І. Слісєєва варто звернути увагу на те, що їх автор був авторитетним кубанським козацьким офіцером, який пройшов шлях від рядового козака - до полковника (Стрелянов, 2001). Під час військової кар'єри він відзначався не тільки вправним командуванням кавалерійських підрозділів, частин і з'єднань, але й був одним із найкращих рубак-джигітів Кубанського козацького війська, здобувши багато військових нагород і отримавши ще більше бойових поранень. До того ж саме він підготував найбільші за обсягом мемуари про участь кубанських козаків у Першій світовій війні, революційних зрушеннях та Громадянській війні 1917-1920 рp. серед усіх представників кубанської козацької еміграції.

Аналізуючи націленість спогадів, варто підкреслити той факт, що попри поразку у жорстокій збройній боротьбі з більшовицьким режимом, яка забрала життя багатьох родичів і товаришів автора, а його самого прирекла на пожиттєву еміграцію, в описі противника він утримується від надто упереджених висловів і принизливих характеристик. Одночасно не впадає він і в глорифікацію Білого руху та кубанських козаків, хоча й не приховує своїх симпатій щодо козацького середовища.

3 огляду на хронологію подій та специфіку бойового досвіду автора всі матеріали було умовно поділено на кілька частин. Тож опис повстання в Кавказькому відділі міститься в окремому виданні «3 Корнилівським кінним», де також подано огляд багатьох фактів і подій, що відбувалися впродовж 1917 -1919 pp. за його участі (Елисеев, 2003). 
При цьому відповідний текст переважно базується на власних спогадах про ті події, в яких безпосередньо брав участь автор. Зрозуміло, що деякі загальнополітичні та військово-стратегічні обставини ще й додатково підкріплюються інформацією, почерпнутою з різноманітної військової документації. Цьому, вочевидь, сприяло й те, що Ф. І. Єлісєєв упродовж Громадянської війни перебував на досить високих військових посадах (командував кубанськими кінними полками і дивізіями), що надало йому можливість отримувати важливу та різноманітну інформацію, якою він вдало підкріплював власні міркування про визначні бойові операції та військово-стратегічні й політичні зрушення тих буремних часів.

Щодо самого козацького повстання в Кавказькому відділі весною 1918 р., то про нього Ф. І. Єлісєєв писав на підставі власного досвіду і 3 урахуванням інформації, отриманої від товаришів по зброї й родичів. Підкреслю, що на момент повстання автор мав чин підосавула i знаходився у станиці Кавказькій, де мешкала його родина. 3 початком повстання досить молодий (йому було лише 25 років), але авторитетний офіцер очолив усю повстанську кавалерію (Елисеев, 2003:182). Тобто, саме він не тільки брав участь в усіх заходах і зборах повстанців та їх проводу, але й безпосередньо керував повстанською кіннотою під час усіх бойових операцій.

Окремо наголошу й на тому, що за участь у повстанні автор «заплатив» високу ціну, бо після поразки козаків більшовики розпочали репресії і застрелили його батька (Стрелянов, 2001). Вочевидь, згадана втрата суттєво позначилася на описі тих трагічних подій, але їх аналіз під таким кутом зору не є метою представленої статті.

3 огляду на зазначене, саме спогади Ф. I. Єлісєєва є надзвичайно цінним джерелом для вивчення воєнного мистецтва кубанської козацької кавалерії під час повстання в Кавказькому відділі Кубанської області весною 1918 р. Поряд із цим, вони є достатньо важливими й для комплексного дослідження ширшої проблематики з історії Кубанського козацтва в умовах Першої світової війни, революції та Громадянської війни.

Ведучи мову про повстання у Кавказькому відділі, треба підкреслити, що його причинами стало загострення протистояння основної маси козаків з більшовицькою владою, яка поступово 
обмежувала їх самоврядування і готувала перерозподіл козацьких земель в інтересах некозацького населення. Безпосередньою ж причиною виступу стало силове роззброєння козаків Кавказького полку та кінної козацької батареї, які після більшовицької мобілізації самовільно повернулися додому разом з усім озброєнням (вогнепальну зброю козаки, на відміну від холодної, завжди отримували від держави) (Леусян, 2007). Згадане роззброєння супроводжувалося зловживаннями червоногвардійських загонів, а тому серед козаків ширилося побоювання грабунків і репресій. До цього додалися й чутки про успішний наступ Добровольчої армії під командуванням Л. Г. Корнілова на Катеринодар (столиця Кубанської області), хоча в реальності ситуація не була надто оптимістичною (Богаевский, 1963:73 - 85; Іванис, 1968:33 - 36).

Повставши проти радянської влади, козаки не тільки виявили свої соціально-економічні та політичні пріоритети, але й підмурівки власної військово-організаційної системи та певні прийоми воєнного і бойового мистецтва. Зрозуміло, що високим рівнем останніх козаки завдячували особливому військовопривілейованому статусу та воєнізованому способу життя. Маю на увазі не тільки тривалу і змістовну військову службу, що супроводжувалась багатолітнім військовим вишколом у стройових частинах, але й воєнізовану підготовку у станичному середовищі (Задунайський, 2006: 51 - 52, 71 - 75; 2012: 304 - 307). Зрозумілим є й вплив безпосереднього бойового досвіду участі у Першій світовій війні абсолютної більшості служивих козаків.

3 огляду на мету пропонованої статті надалі зосереджу свою увагу на вияві та аналізі особливостей застосування козацькою повстанською кавалерією базисних прийомів і принципів воєнного мистецтва, зафіксованих у спогадах Ф.І.Єлісєєва. I розпочну 3 опису першої бойової операції повстанської кавалерії - звільнення станиці Темижбекської.

Ця операція відбулася згідно 3 рішенням зборів повсталих козаків у станиці Кавказькій 19 березня (1 квітня за новим стилем) 1918 р. у відповідь на звернення представників станиці Темижбекської (Леусян, 2007). I треба відразу звернути увагу на застосування звичного принципу блискавичних зборів козаків у похід. Про це автор спогадів пише таке (тут і надалі цитуватиму першоджерело у власному перекладі, бо оригінал написано російською мовою): «На правах командира сотні, котру складали 
зараз кавказці та темижбекці, - гучно звертаюся до маси: Кавказці! По домівках! Усім зібратися верхами (верхи) на конях зі зброєю у нової старовірської церкви! I звідти - на Темижберх! - закінчив я по-станичному... козаки станиці Кавказької, швидко висипали 3 бараку і побігли по домівках за своїми стройовими кіньми. Вулицею Красною 3 широким полковим прапором i двома сотенними (2-ї і 3-і), які зберігались у нашому будинку, - 3 групою темижбекських козаків-гінців, розбризкуючи весняну сльоту копитами коней, - крупною риссю йдемо до східного краю станиці». (Елисеев, 2003:177).

Наведена інформація свідчить. що козаки миттєво засідлали своїх коней і зі зброєю подалися на збірний пункт. Згадані дії $\epsilon$ важливою передумовою для здійснення будь-яких бойових операцій, що потребують мобілізації сил. Тут і надалі подібні прийоми, що мають ознаки певних стратегем, називатиму за допомогою як наукової термінології, так і 3 використанням влучних козацьких або українських народних висловів (такий підхід неодноразово апробовано в низці попередніх статей (Задунайський, 2017; 2018: 2019; 2020). Тож козаки задіяли метод швидкої мобілізація, яку можна ще назвати «Сполохом».

Саме звільнення станиці Темижбекської Ф. І. Єлісєєв подає так: «На широких рисях, пройшовши 12 верст, - сотня увірвалася до Темижбекської. Один взвод було вислано для захоплення вокзалу. 3 трьома іншими, перейшовши у чвал, - вулицею Красною кинулися до станичного правління...Зайнявши вулиці поблизу правління і швидко вишикувавши сотню у головного фронту, - зі Стуколовим і безпалим Чаплигіним увійшли до правління... Поява нашої сотні була повною несподіванкою для станичної ради... Розпустивши станичну раду темижбекців і через комісара наказавши усе озброєння вантажити на підводи, вийшов зі своїми стариками до сотні..» (Елисеев, 2003: 178 - 179).

Цей короткий опис є дуже чітким та насиченим важливою інформацією про основні прийоми тактичних дій козацької кінної сотні під час захоплення станиці. Йдеться, зокрема, про вияв бойової ініціативи («Під лежачий камінь вода не тече»), належну дисципліну та чітке виконання наказів («Добрий козак баче, де отаман скаче»), одночасні дії у різних напрямках («На всі боки»), рішучість («Або пан - або пропав»), використання розвідданих («Все бачити і чути, щоб нічого не оминути»), залучення своїх 
прибічників у станиці та станичній раді («Бити зсередини») та захоплення зброї й бойової амуніції («Хліб козацький»). При цьому найважливішою передумовою успіху операції став фактор несподіваності, бо повстала козацька кіннота «заскочила зненацька» свого противника, а також випередження противника, не дарма ж кажуть, що «хто рано встає - тому й Бог дає».

Окремо наголошу на тому, що повстанці під час здобуття станиці головну увагу приділили взяттю під контроль основної адміністративної будівлі станиці (станичного правління), в якій функціонував осередок більшовицької влади, та місцевого опорного пункту залізничної комунікації (залізничної станції). Інакше кажучи, козаки застосували стратегему атаки найважливіших пунктів противника («Бий у пику - ноги самі впадуть»).

Згадані 10 принципів-прийомів воєнного мистецтва кінної сотні з огляду на обставини виявилися оптимальними і забезпечили цілковитий успіх першій бойовій операції козаків-повстанців. Окремо наголошу на тому, що в силу специфіки ситуації козацька кавалерійська сотня діяла виключно в кінному ладі і не застосовувала спішування, бо все залежало від випередження противника завдяки рухливості та швидкості дій кінноти. Тому й операція мала ознаки неочікуваного і блискавичного наскоку на станицю, що унеможливило зайняття противником оборонних позицій та здійснення організованого опору.

Ситуація змінилася 24 березня (6 квітня за новим стилем) 1918 р., коли повстанське командування за підсумком розширеної військової наради здійснило широкомасштабну бойову операцію усіма наявними силами (понад 7.000 бійців, зокрема, понад 1.000 кіннотників; 4 кінних гармати і 40 кулеметів (Елисеев, 2003: 187). При цьому найбільш рухливе та дієздатне формування повсталих козаків - кінний загін під командуванням Ф. І. Єлісєєва - розпочав бойові дії найраніше, ще й мало виконати кілька завдань, на відміну від решти. Саме тоді козацька кавалерія знову виявила низку дієвих прийомів і принципів ведення бою.

Розпочну аналіз 3 огляду виступу цього загону, про що Єлісєєв згадував наступне: «Опівночі кіннота повстанців, до одної тисячі козаків, повинна виступити в степ... 3 Богом... за мною, - тихо я сказав головній темижбекській сотні і, хрестячись, рушив на іï чолі. Ми на західній околиці станиці. Тиша навколо. Станиця спить». (Елисеев, 2003: 188 - 189). Отже, козаки розпочали 
операцію вночі, коли противник найменше очікував їх активних дій. Такий підхід цілком відповідав традиційній стратегемі ведення бойових дій вночі - «Місяць - козацьке сонечко».

Після виступу зі станиці загін кінноти швидко дістався до першого ворожого пункту, де згідно з планом розпочав руйнування комунікацій противника. У мемуарах читаємо: «Верст п'ятнадцять до Рогачівського роз'їзду пройшли швидко. Головний взвод зайняв його. Здобутими тут інструментами разгвинтили рейки та відтягнули їх. Темижбекський козак Козьмінов заліз на телеграфний стовп і шашкою перерубав провода...». (Елисеев, 2003: 189). Ці факти свідчать, що козаки швидко і досить вправно зруйнували як залізничне сполучення 3 ворожим центром, так і засоби зв'язку, а це було важливим проявом застосування принципу руйнування тилових комунікацій ворога («Руйнація запілля»).

Такі дії стали вагомою запорукою для забезпечення успіху подальшої бойової акції. Важливою видається й інформація про дієздатність авангарду - головного взводу, який несподівано для противника захопив пункт його комунікацій. Тобто, окрім вправного поєднання бойової охорони («Береженого Бог береже, а козака шабля стереже») та розвідки («Все бачити і чути, щоб нічого не оминути»), ще й застосовано принцип несподіваної атаки («Заскочити зненацька»).

Загін швидко рухався далі, беручи під контроль чергові опорні пункти противника. Ф. І. Єлісєєв про це згадує з належною увагою: «Миттю захопили станцію Мілованово, що поблизу станиці Казанскої. Начальнику станції розповідаю про повстання козаків. Даю вказівку: «Не приймати потягів». I, залишивши один взвод тут, гумнами рухаюся до станиці» (Елисеев, 2003: 190). Здобуття чергової станції супроводжувалося залишенням у ній козацької залоги, що свідчило про слушне застосування принципу закріплення за собою важливого опорного пункту, а це відповідало й звичній стратегемі щодо вибору та контролю вдалої позиції («Таборування»). Завдяки таким діям вдалося частково унеможливити й проникнення у власне запілля ворожих підрозділів та розвідників.

Поряд із цим продовжувалося поширення повстання у навколишніх станицях і цьому сприяло залучення місцевих козаків. Саме так розгорталися події у станиці Казанській, що 
знаходилася поблизу згаданої станції. У мемуарах цьому присвячено наступні рядки: «Якась фігура на коні, у тужурці, але в папасі і з карабіном через плече, швидко наближається до голови колони...Це виявився комісар станиці Казанської хорунжий Подимов...Привітавшись і дізнавшись, «хто я»- рушив 3 нами прямо на станичний майдан, кажучи, що у нього «все приготоване». I дійсно: у правлінні перебувало кілька озброєних козаків. Гукнувши когось по імені, наказав негайно «бити набат»...» (Елисеев, 2003:190 - 191).

Наведені факти свідчать про вдале залучення місцевих козаків, які не тільки надавали необхідну інформацію (певний вияв розвідувальних дій «Все бачити й чути, щоб нічого не оминути»), але й заздалегідь готували повстання у своїх станицях, підриваючи в них позиції радянської влади («Бити зсередини»).

У звільненій станиці після підтримки повстання більшістю іiі козацького населення одразу відновилося функціонування місцевого козацького самоврядування на чолі з отаманом (тим самим «комісаром» хорунжим Подимовим). Воно організувало забезпечення повстанців харчами та фуражем, ще й роззброїло місцевих прибічників радянської влади, а найбільш активних серед них заарештувало. Ф. І. Слісєєв, згадуючи ті події, пише: «На площі з'явилося сіно, зерно, хліб, сало, молоко. Почалося роззброєння іногородніх. Головних, із запотиличниками, відправляли до каземату при правлінні. I все це було так просто, рішучо й вправно...» (Елисеев, 2003: 192). 3 цього опису випливає факт не тільки дієздатності традиційного козацького самоврядування, але й застосування деяких принципів воєнного мистецтва. Йдеться про матеріальне забезпечення повстанців, у тому числі завдяки захопленню ворожого озброєння (стратегема «Хліб козацький»). Досить слушним став й арешт місцевих більшовицьких активістів, що не тільки настрахало і деморалізувало їх прихильників, але й унеможливило вірогідність удару в спину (стратегема «Попереднього настрахання»).

Одночасно зі згаданим відбувалися й мобілізаційні заходи щодо формування бойових загонів, які вливались до складу об'єднаних сил повстанців Кавказького відділу. При цьому поголос про повстання швидко ширився навкруги, що обумовило подібні процеси в сусідніх станицях. В мемуарах цей процес проілюстровано наступним уривком: «Одразу ж збирав козаків 
(йдеться про станичного отамана), роздавав гвинтівки, ставив їх до лав...Сотня пластунів чоловік 3200 і півсотня кінноти вже влилися до нас. Пластунів очолив підосавул Іван Іванович Коробко, одноліток і товариш по Майкопському технічному вчилищу, котрого я не бачив рівно десять років. Тріумфування всіх було повне... Години до десятої ранку сюди прибула сотня козаків станиці Тифліської. Її привів хорунжий Саморядов» (Елисеев, 2003: 192).

Отже, традиційна модель козацької мобілізації одразу почала успішно реалізовуватися (вчергове задіяно стратегему «Сполох»), ще й супроводжувалась співпрацею сусідніх козацьких середовищ («Гуртом і батька легше бити»). Завдяки цьому, у разі безперешкодного поширення козацького повстання на весь Кавказький відділ, можна було очікувати на кількаразове збільшення військ повстанців, що стало б важливою передумовою для успішного загальнокозацького повстання в межах колишньої «Кубанської області».

Після звільнення станиці Казанської та поширення повстання на сусідні станиці й хутори, поповнений добровольцями кінний загін на чолі з Ф. І. Слісєєвим продовжив виконання бойових завдань. Йдеться, зокрема, про захоплення ворожого потягу із застосуванням певних прийомів воєнного мистецтва. У спогадах це описується наступним чином: «І Зз загоном скачу туди. Попереду великий полковий прапор на високому древку. Він військового кольору, тобто червоний....Сотні спішено й вони залягли в канавах гумен. Поїзд підійшов та зупинився. Він був товарно-пасажирським. Сталася помилка. 3 кількома козаками проходимо вагонами. Роззброїли кількох червоногвардійців, поїзд затримали, виставивши охорону...» (Елисеев, 2003: 192).

3 наведеної інформації випливає, що козаки-повстанці використали свій військовий прапор, який був червоного кольору, чим частково дезорієнтували противника (стратегема «Замилити очі»). Безпосередні дії відбувалися швидко й рішучо (принцип бойової дії/стратегема «Або пан - або пропав») та виявились у блискавичному застосуванні засідки спішених козаків обабіч залізничного шляху (військові хитрості «Взяти у матню» та «Заскочити зненацька»). Також є підстави вести мову про утримування козаками бойової ініціативи (стратегема «Під лежачий камінь вода не тече»). Вже у захопленому потязі було роззброєно 
та заарештовано групу настраханих червоноармійців («Попереднє настрахання» та «Хліб козацький»). Поряд із успіхом цієї сутички, треба звернути увагу й на певний недолік-отримана інформація (вочевидь розвідувального характеру) про поїзд виявилася помилковою, бо заміть крупного ворожого загону там перебував лише невеликий підрозділ охорони.

Згадане бойове зіткнення виявилося останнім успіхом кінного загону під командуванням Ф. І. Слісєєва того дня. Причиною стало те, що на основному напрямку наступ головних сил повсталих козаків провалився. Війська Червоної Армії завдали несподіваного удару і розбили їх. Після цього частина червоного угрупування здійснила переслідування залишків деморалізованих повстанців, а інша за підтримки броньованого потягу несподівано контратакувала загін Ф.І. Єлісєєва в станиці Казанській.

У спогадах цей епізод повстання змальовано так: «...3-під балки, до Казанської, тихо виповзав бронепотяг і на ходу відкрив по ній шрапнельний вогонь... Все стало ясніше - ясного - наших разбито і вони відійшли. Без кулеметів, без гармат - кіннота не могла захистити станицю проти бронепотягу, якого підтримувала піхота. Треба було відходити в степ і пробиватися до Кавказької, до головних сил...» (Елисеев, 2003: 193).

Хочу підкреслити, що рішення про відступ до станиці Кавказької було цілком логічним, але нездійсненним, бо на той момент противник вже захопив станицю. Це знаменувало поразку цілого повстання та зводило нанівець будь-які спроби командування кінного загону зберегти його боєздатність та спробувати виправити ситуацію.

Тож після підтвердження інформації про повну поразку основних сил та захоплення центру повстання козаки-кіннотники втратили віру в перемогу та почали самовільно повертатися у рідні станиці й хутори. Автор згадуе про це такими рядками: «Сонце було на закаті, і з його промінням, що відходило, - козаки, відділяючись від загальної маси групами і цілими взводами, прямували до своїх станиць. Досягли шляху Кавказька Дмитріївська.... Цей широкий шлях - був вирішальним. Тут козаки зовсім перестали коритися своїм офіцерам. Командир Дмитрїівської сотні, сильно скороченої, молодший урядник Анцупов-старший, моєї 2-ї сотні по Фінляндії, по-братерські сказав мені: «Куди ж ідти, Федоре Івановичу? Я поведу свою сотню додому...»- i, повернувши на північ, - вирушив.... У степу, у витоках болотистої 
річки Челбаси, тримаючи коней у поводу, скрючившись від холоду, дрімали чотири офицери: два брати Єлісєєви, Храмов і Жарков. Це було все, що залишилося від тисячного загону кінноти повстанців...» (Елисеев, 2003: 195-196).

Отже, найбоєздатніше формування повсталих козаків через втрату бойового духу і масову деморалізацію припинило своє існування впродовж кількох годин. Цей випадок підтвердив мінливість настроїв повстанських формувань у залежності від оперативної ситуації та поширення панічних чуток. Саме тому не вдалося реалізувати слушне рішення Ф. І. Єлісєєва - відвести кінний загін до окружного вишкільного табору над р. Челбаси (Елисеев, 2003: 194).

Нагадаю, що в той час у межах кожного відділу існували подібні табори, в яких були необхідні приміщення та певне устаткування для проведення кількатижневих навчальних зборів козацьких кінних, кінно-артилерійських та піхотних (пластунських) частин і підрозділів (Задунайський, 2004: 271-276; 2006: 89-94). За тих обставин такі дії видаються єдино можливими для збереження бойового потенціалу повстанців на майбутнє.

До речі, такий намір Ф. І. Єлісєєва свідчив і про спробу використання звичної стратегеми щодо збереження бойового потенціалу за несприятливих обставин у спосіб вправного відступу («Козак як не переміг, то викрутився»). Ї̈̈ не вдалося успішно застосувати, бо більшість козаків, втративши бойовий дух та піддавшись панічним настроям, негайно поверталася додому, а не намагалася у такий спосіб зберегти боєздатне повстанське формування.

Завершивши огляд дій козацької кінноти під командуванням Ф. І. Слісєєва, хочу наголосити на тому, що він вповні підтвердив залежність загального успіху широкомасштабної бойової операції від низки причин та факторів, серед яких важливу роль відіграє злагодженість дій усіх частин і підрозділів, які беруть у ній участь. Тож навіть низка успішних дій окремого кінного загону не забезпечила загальної перемоги повстанців.

Далі пропоную короткий перелік основних характеристик та проявів воєнного мистецтва козацької кінноти на чолі з Єлісєєвим, застосованих під час повстання проти більшовиків у Кавказькому відділі колишньої «Кубанської області» весною 1918 р.

Перш за все, наголошу на вправних діях у кінному ладі, що не тільки забезпечило значну швидкість пересувань цьому загону, але й сприяло маневреності та було важливою передумовою 
несподіваних атак на опорні пункти противника, включно iз потягами. Досить вдалим виявився i спосіб пересування у маршових кінних колонах із передовою бойовою сторожею, що дуже добре орієнтувалася на місцевості та здійснювала тактичну розвідку по ходу свого просування. Командування повстанської кінноти діяло вправно i не тільки чітко виконувало поставлені завдання, але й проявляло належну ініціативу та гнучкість у залежності від актуальних викликів бойових зіткнень. Відзначу й те, що козацька кіннота в черговий раз підтвердила здатність у разі потреби швидко спішуватись для ведення бою в пішому ладі.

Окремо зупинюся на певному організаційному недоліку кінного загону - відсутності кінно-гарматного підрозділу. При цьому кінні гармати повстанці мали, але згідно 3 планом бою намагалися їх застосувати на іншому операційному напрямку. Такі обставини суттєво ослабили бойову міць і здатність діяти проти різноманітних угруповувань противника кінноти Ф. І. Єлісєєва. Наочним прикладом цього став контрнаступ червоноармійського угруповування на станицю Казанську із залученням броньованого потягу, який неможливо було стримати без артилерії.

Треба нагадати, що бойовий досвід та особливості військової структури кубанських козацьких частин враховували такі потреби. Підкреслю, що загін чисельністю понад 1.000 шашок дорівнював кінній бригаді, яка самостійні бойові операції могла виконувати із використанням кінної батареї (до 6 гармат). Нагадаю, що напередодні та під час Першої світової війни до складу козацької кінної дивізії входили 4 полки (об’єднувалися у 2 бригади) та 1 кінно-гарматний дивізіон (у складі 2 батарей) (Задунайський, 2006: 76, 101). Тож кінноті козаків-повстанців вкрай були потрібні хоча б кілька гармат.

Окремо наголошу на застосуванні козацькою кавалерією впродовж повстання 20 принципів-стратегем-військових хитрощів під час бойових зіткнень, що забезпечили їм кілька відчутних перемог над противником:

1. Випередження - «Хто рано встає - тому й Бог дає».

2. Атаки у важливі місця - «Бий у пику - ноги самі впадуть».

3. Ведення бойових дій вночі - «Місяць - козацьке сонечко».

4. Неочікуваний удар - «Заскочити зненацька».

5. Захоплення військової здобичі - «Хліб козацький». 
6. Ініціатива в бою - «Під лежачий камінь вода не тече».

7. Залучення до повстання козаків - «Гуртом і батька легше бити».

8. Дезорганізація комунікацій противника - «Руйнація запілля».

9. Ведення бойових дій у різних напрямках - «На всі боки».

10. Приховування стану/приналежності військ - «Замилити очі».

11. Деморалізація противника - «Попереднє настрахання».

12. Швидка мобілізація - «Сполох».

13. Дотримання дисципліни - «Добрий козак баче, де отаман скаче».

14. Рішучі та відчайдушні дії - «Або пан - або пропав».

15. Розвідка - «Все бачити й чути, щоб нічого не оминути».

16. Дії у запіллі противника - «Бити зсередини».

17. Вибір вдалої позиції - «Таборування».

18. Заманювати у пастку - «Взяти у матню».

19. Бути напоготові - «Береженого Бог береже, а козака шабля стереже».

20. Рятування основних сил за переваги противника - «Козак як не переміг, то викрутився» (частково).

Висновки. Отже, у спогадах Ф. І. Слісєєва в силу того, що він, будучи авторитетним козацьким офіцером-кіннотником, брав безпосередню участь у антибільшовицькому повстанні кубанських козаків Кавказького відділу весною 1918 р. і командував усією кавалерією, міститься цінна інформація про особливості ії воєнного мистецтва на оперативно-тактичному рівні. Воно виявилося досить різноманітним і дієвим, особливо під час ведення бою у кінному ладі. Маневреність, рухливість, бойова злагодженість, високий рівень індивідуальної боєздатності та різноманітність бойових прийомів, зокрема 20 принципів-стратегем-військових хитрощів, разом із командним хистом проводу на чолі 3 Ф. І. Єлісєєвим забезпечили перевагу кінноті козаків-повстанців над противником у більшості бойових зіткнень. Запорукою цього, вочевидь, став попередній бойовий досвід та воєнізований спосіб життя козацької верстви.

При цьому лише успішних дій кінного загону виявилося замало для здобуття загальної перемоги повстання за умови поразки основних сил на головному напрямку бойових дій під час визначальної бойової операції 24 березня (6 квітня) 1918 р. 
Поряд із високою боєздатністю козацької кінноти варто наголосити на психологічній вразливості повстанців. Раптове ускладнення бойової ситуації внаслідок поразки основного угруповування повстанців та помітна оперативна перевага противника вкрай негативно вплинули на більшість козаківкіннотників. Вони втратили бойовий дух і піддалися паніці, що унеможливило збереження кінного повстанського загону для продовження збройної боротьби. Доводиться визнати, що саме це виявилося «ахіллесовою п'ятою» усього козацького повстання в Кавказькому відділі колишньої «Кубанської області» весною 1918 року.

У цій статті за матеріалами спогадів Ф. І. Єлісєєва досліджено лише один $з$ аспектів воєнного мистецтва кубанських козаків під час антибільшовицького повстання у Кавказькому відділі весною 1918 р. Цей приклад має посприяти активізації відповідних досліджень в історіографії.

\section{Використані посилання}

Авраменко А.М., Фролов Б.С.,Чумаченко В.К. (2007). Козащьке військо на Кубані. Історія Украӥнського Козаитва. Нариси у 2 m. Київ: Вид. дім “КиєвоМогилянська академія", Т. II, с. 364-414.

Білий Д.Д. (2009). Україниі Кубані в 1792-1921 роках. Еволюиія соиіальних ідентичностей. Львів-Донецьк: Східний видавничий дім, с. 543.

Богаевский А.П. (1963). Ледяной поход. Воспоминания 1918 г. Нью-Йорк, с. 150.

Елисеев Ф.И. (2003). С Корниловским конным. Москва: ООО «Издательство АСТ»; ООО «Издательство Астрель», с. 655.

Задунайський В.В. (2004). Козацькі учбові збори початку XX ст. - центри вишколу 3 козацького військового та бойового мистецтва. Украйнський історичний збірник. Вип. 7, с. 268-279.

Задунайський В.В. (2006). Бойове мистеитво та військова спадщина украӥнських козаків в кіниі XIX - на початку XXI cm. Донецьк: Норд-ПресДонНУ, с. 335.

Задунайський В.В. (2008). Військова організація та бойові дії донських і українських кубанських козаків під час революції 1917-1921 pp. Історичні $i$ політологічні дослідження, № 3-4, с. 46-52.

Задунайський В. (2012). Запровадження гімнастики в станичних школах Кубанського козацтва на початку XX ст. Історичні і політологічні дослідження, № 1, с. 302-309.

Задунайський В.В. (2017). Військове мистецтво запорожців часів Хотинської війни 1621 р. та його аналоги в «Мистецтві Війни» Сунь-Дзи: універсальність і самобутність. Історичні і політологічні дослідження, № 1, С. 17-29.

Задунайський В.В. (2018). Козацькі стратегії і стратегеми під час кампанії 1649 р. та їхні аналоги у «Стратегемах» Секста Юлія Фронтіна. Історичні $i$ політологічні дослідження, № 2 (63), с. 31-44. 
Задунайський В.В. (2019). Військові хитрощі кубанських козаків під час антибільшовицького повстання у Баталпашинському відділі влітку 1918 р. за спогадами А.Г. Шкуро. Військово-науковий вісник, Вип. 32. с. 121-134.

Задунайський В. (2020). Військова хитрість «заскочити зненацька» в перших боях махновців і кубанських козаків-повстанців у 1918 р. Lituanistyka $i$ wschodoznawstwo, Poznań: Wydział Historii UAM, s. 359-369.

Іванис В. (1968). Боротьба Кубані за незалежність. Мюнхен, с. 138.

Карпенко С.В. (2006). Очерки истории белого движения на Юге России (1917-1920 г2.). Москва: Издательство Ипполитова, с. 456.

Леусян О.А. (2007) «Фронт без линии фронта»: казачьи восстания на Кубани весной 1918 года. Доступно: http://slavakubani.ru/kkv/history/1917-1920/front-bez-liniifronta-kazachi-vosstaniya-na-kubani-vesnoy-1918-goda/ [Дата звернення 11 марта 2021]

Ратушняк В.Н. (1996). Очерки истории Кубани с древнейших времен по 1920 2. Краснодар: Советская Кубань, с. 656.

Ратушняк О.В. (2005). Политические искания Донского и Кубанского казачества в годы Гражданской войны в России (1918-1920 гг.). Казачество России в Белом движении. Белая Гвардия. Альманах № 8. Москва. с. 17-23.

Стрелянов (Кулабухов) П. (2001) Федор Елисеев: офииер, джигит, писатель. Доступно: http://www.gipanis.ru/?level=989\&type=page. [Дата звернення 11 марта 2021].

\section{References}

Avramenko A.M., Frolov B.E., Chumachenko V.K. (2007). Cossack army on the Kuban. History of Ukrainian Cossacks. Essays in 2 vol. Kyiv: Publishing House «Kyiv-Mohyla Academy». Vol. 2, pp. 364-414 (ukr).

Bilyi D.D. (2009). Ukrainians of Kuban in 1792-1921. Evolution of social identities. Lviv; Donetsk: Oriental Publishing House, p. 543 (ukr).

Bogaevsky A.P., (1963). Ice hike. Memories 1918. New York, p. 150 (rus).

Eliseev F.I., (2003). With the Kornilov Cavalry Regiment. Moscow: LLC "AST Publishing House"; LLC «Astrel Publishing House», p. 655 (rus).

Zadunaiskyi V.V. (2004). Cossack training camps of the early twentieth century training centers for Cossack martial arts. Ukrainian historical collection,. Issue 7, pp. 268-279 (ukr).

Zadunaiskyi V.V. (2006). Martial art and military heritage of Ukrainian Cossacks in the late XIX - early XXI century. Donetsk: Nord-Press - DonNU, p. 335 (ukr).

Zadunaiskyi V.V. (2008). Military organization and military operations of Don and Kuban Cossacks during the revolution of 1917-1921. Historical and political research, № 2-3, pp. 46-52 (ukr).

Zadunaiskyi V. (2012). Introduction of gymnastics in the schools of the Kuban Cossacks in the early XX century. Historical and political research, № 1, pp. 302-309 (ukr).

Zadunaiskyi V.V. (2017). Martial Arts of the Cossacks of the Khotyn War of 1621 and its Analogues in Sun-Ji's Art of War: Versatility and Originality. Historical and political research, № 1, pp. 17-29 (ukr).

Zadunaiskyi V.V. (2018). Cossack strategies and stratagems during the 1649 campaign and their counterparts in the work of Sextus Julius Frontin's "Strategies". Historical and political research, № 2 (63), pp. 31-44 (ukr).

Zadunaiskyi V.V. (2019). Military tricks of the Kuban Cossacks during the antiBolshevik uprising in the Batalpashin district in the summer of 1918, according to the memories of A.G. Shkuro. Military-scientific journal, Issue 32. pp. 121-134 (ukr). 
Zadunaiskyi V. (2020). Military tricks "surprise" in the first battles of the Makhnovists and Kuban Cossack insurgents in 1918. Lituanistyka $i$ wschodoznawstwo, Poznań: Wydział Historii UAM, pp. 359-369 (ukr).

Ivanys V. (1968). The struggle of Kuban for independence. Munich, p. 138 (ukr).

Karpenko S.V. (2006). Essays on the History of White movement in the South of Russia (1917-1920). Moscow: Ippolitov Publishing House, p. 456 (rus).

Leusyan O.A. (2007). "Front without a front line": Cossack uprisings in the Kuban in the spring of 1918. URL: http://slavakubani.ru/kkv/history/1917-1920/frontbez-linii-fronta-kazachi-vosstaniya-na-kubani-vesnoy-1918-goda/ [2020, March 11] (rus).

Ratushniak V.N. (1996). Essays on the history of the Kuban from ancient times to 1920. Krasnodar: Soviet Kuban, p. 656 (rus).

Ratushniak O.V. (2005). Political searchings of Don and Kuban Cossacks during the Civil War in Russia (1918-1920). Russian Cossacks in the White movement. White Guard. Almanac, Moscow, № 8, pp. 17-23 (rus).

Strelyanov (Kulabukhov) P. (2001). Fyodor Eliseev: officer, horseman, writer. URL: http://www.gipanis.ru/?level=989\&type=page[2020, March 11] (rus)

\section{Zadunaiskyi V. \\ MEMOIRS OF F.I. ELISEEV - SOURCE FOR THE STUDY OF THE KUBAN COSSACK CAVALRY MILITARY ART DURING THE ANTI-BOLSHEVIK UPRISING IN THE CAUCASUS DISTRICT IN THE SPRING OF 1918.}

In March 1918, the Kuban Cossacks in the Caucasus region raised the first major uprising against the Bolshevik regime. During the uprising, the Cossack cavalry played an important role. A very valuable source for studying the military art of the Cossack cavalry during this uprising are the memoirs of Fedir Eliseev. He was a young but authoritative Cossack cavalry officer. During the uprising, Fedir Eliseev led the entire cavalry of the Cossacks and took part in all battles. The Cossacks had a high level of individual and collective combat training due to the paramilitary way of life and combat experience (especially during the First World War). The military art of the Cossack cavalry had its strengths during the uprising: the Cossacks fought very well on horseback; they could quickly dismount and fight like infantry; the cavalry moved very fast and maneuvered deftly; the Cossacks used 20 stratagems (partially 1); the detachment of the advanced guard acted qualitatively, especially during the night offensive. Due to this, the cavalry of the insurgent Cossacks won most of the battles. The Cossack cavalry also found shortcomings: there were no cavalry artillery in the large cavalry detachment; the defeat of the main forces of the insurgents led to the demoralization of the Cossack cavalry and mass desertion. The uprising was suppressed, but the Cossack cavalry demonstrated: a high level of combat training, a variety of tactics, sufficient coordination of units in battle, and skilful command. The memoirs of Fedir Eliseev describe important manifestations of high-quality military art of the cavalry of the insurgent Kuban Cossacks.

Keywords: Military art, stratagems, the Kuban Cossacks, cavalry, Fedir Eliseev, memories, uprising, 1918, the Bolshevik regime, the Caucasus District. 